\title{
ECO-FRIENDLY USE OF EGGSHELL POWDER AS A BIO-FILLER AND FLUX MATERIAL TO ENHANCE TECHNOLOGICAL PROPERTIES OF FIRED CLAY BRICKS
}

\author{
Blasius Ngayakamo ${ }^{1 *}$, Assia Mahamat Aboubakar ${ }^{l}$, Charles Gbetoglo \\ Komadja ${ }^{l}$, Abdulhakeem Bello ${ }^{1,2}$, Azikiwe Peter Onwualu ${ }^{l}$ \\ ${ }^{1}$ Department of Materials Science and Engineering, African University of Science and \\ Technology, Abuja Nigeria \\ ${ }^{2}$ Department of Theoretical and Applied Physics, African University of Science and \\ Technology, Abuja Nigeria
}

Received 24.12.2020

Accepted 03.05.2021

\begin{abstract}
In this work, an experimental investigation on the use of eggshell powder from waste eggshells as an alternative source of bio-filler and flux to enhance the technological properties of fired clay bricks were carried out. Four different batch compositions were formed with eggshell powder as a bio-filler and flux replacing clay-soil up to $15 \mathrm{wt} . \%$. The clay bricks were prepared by the casting method and were fired at 800,900 , and 1000 ${ }^{\circ} \mathrm{C}$ at the heating rate of $8{ }^{\circ} \mathrm{C} / \mathrm{min}$ for 120 minutes. The raw materials and produced fired clay bricks were characterized by SEM/EDS, XRF, and XRD, respectively. Besides, technological properties of fired clay bricks (eg. water absorption, apparent porosity, bulk density, and compressive strength) were also determined. The results showed that adding 15 wt.\% of eggshell powder as a bio-filler and flux yielded a compressive strength of 4.8 $\mathrm{MPa}$, the bulk density of $2.1 \mathrm{~g} / \mathrm{cm}^{3}$, and a lower water absorption value of $11.1 \%$ at the firing temperature of $1000{ }^{\circ} \mathrm{C}$. Consequently, the use of eggshell as a bio-filler and flux to enhance the technological properties of fired clay bricks is promising and can be considered as an effective alternative method to reduce environmental concerns caused by inappropriate discarding and landfill construction to dispose of eggshell waste.
\end{abstract}

Keywords: Eggshell powder; bio-filler and flux; fired clay bricks and; technological properties.

\section{Introduction}

Fired clay bricks (FCBs) are materials of interest in the construction industry due to their excellent physical-mechanical, thermal properties, and durability $[1,2]$. They are

*Corresponding author: Blasius Ngayakamo,bngayakamo@aust.edu.ng 
common building materials since ancient times and are presently still used for the construction of huge structures [3, 4]. They are economical products made from cheap, abundant raw materials, including clay, sand, and water, through a simple fabrication process $[5,6]$. However, FCBs are becoming less competitive than other construction materials like cement and concrete blocks because of their limited mechanical strength. Thus, due to their irrefutable application for a long time, the quality of FCBs continues to improve globally for modern construction [7, 8]. Nonetheless, the production of FCBs has been observed to demand a high amount of energy to vitrify the clay bricks during a sintering process. Therefore, fillers and fluxes have been considered to be the best possible way to save energy during brick production by reducing firing temperature and time.

As a result, recently the introduction of fillers in clay-based bricks with various industrial wastes to improve the physical-mechanical properties of fired brick products has caught the attention of many researchers around the globe. Several fillers from agricultural and industrial waste particles such as waste glass sludge [9], rice husks ash [10], granite and marble sawing waste [11], paper residues [12], and marble powder [13], have been incorporated in clay bricks and have improved the technological properties of FCBs.

Eggshell is an agricultural waste that is discarded from food processing industries, which has caused environmental problems due to improper disposal in our surroundings $[14,15]$. It is estimated that by 2030 , the global production of eggs will reach 90 million tons which will result in the enormous production of eggshell waste [16 17]. According to food and agricultural organization (FAO) statistics, it is estimated that 6.4 million tons of eggshell waste are discarded and disposed of in landfills worldwide annually [18]. The inappropriate discarding and increasing costs of disposing of eggshell waste have been an area of environmental concern for food processing industries due to the development of urban pests and the availability of disposing sites [19-21]. According to Environmental Protection Agency (EPA), eggshell waste is ranked $15^{\text {th }}$ position as the major food processing environmental problem, and health hazards waste by the European Union due to the growth of fungi caused by their biodegradation [18, 22, 23]. Furthermore, the disposal of eggshell waste in landfills has caused environmental concerns due to the development of pathogens, and their decomposition has generated significant odour to the environment $[20,24,25]$.

It is, therefore, essential to look for an alternative way to convert eggshell waste into valuable raw materials for several industrial applications. Subsequently, the recycling of eggshell waste has attracted the attention of many scientists and engineers in construction industries around the globe as it has been a very promising research area, particularly in reducing the cost of building materials [26]. Several works have been reported on the use of eggshell powder as a cement replacement material in the manufacture of concrete [27-34]. On the contrary, there have been very few reports on the incorporation of eggshell waste for the production of fired clay bricks and other claybased building materials [35-37]. In summary, few research works have been done on using raw eggshell waste to improve the physical-mechanical and thermal properties of clay-based building materials, which has been practicable to enhance their properties. Therefore, it is considered the promising field of materials science and engineering, which requires more in-depth research to provide cheap and yet functional and durable building materials in the future. However, the current work investigates the use of the calcined 
eggshell powder as a bio-filler and flux to enhance the technological properties of fired clay. The use of calcined eggshell powder as a bio-filler to enhance the technological properties of FCBs is expected to have both environmental and economic benefits by utilizing eggshell waste as zero-cost raw material while ensuring a clean and sustainable environment that is free of wastes.

\section{Experimental Work}

The clay-soil and eggshell waste were gathered from Abuja on the coordinates $(\mathrm{N}$ $\left.9^{\circ} 4^{\prime} 0.0012^{\prime \prime}\right)$ and (E $\left.7^{\circ} 28^{\prime} 59.9988^{\prime \prime}\right)$ in Nigeria at 491m. The eggshells were washed with water and were then dried in an oven at $110{ }^{\circ} \mathrm{C}$ for the duration of $2 \mathrm{~h}$. The eggshell waste was calcined at $900{ }^{\circ} \mathrm{C}$ at a heating rate of $5{ }^{\circ} \mathrm{C} \mathrm{min}-1$ for the duration of $1.5 \mathrm{~h}$ to decompose calcite $\left(\mathrm{CaCO}_{3}\right)$ and other organic matters. The clay soil was crushed and milled by Retsch BB-50, 240v,50Hz for a duration of 80 min while calcined eggshell for $120 \mathrm{~min}$. The milled raw materials were passed through a $<1 \mathrm{~mm}$ mesh plate for clay soil and calcined eggshell through $<0.425 \mathrm{~mm}$ mesh plate size by the sieve shaker with a serial number; $1217141234,240 \mathrm{v}, 50 / 60 \mathrm{~Hz}$. The preparation of the samples was intended to obtain fine powder particles, as shown in Fig.1.
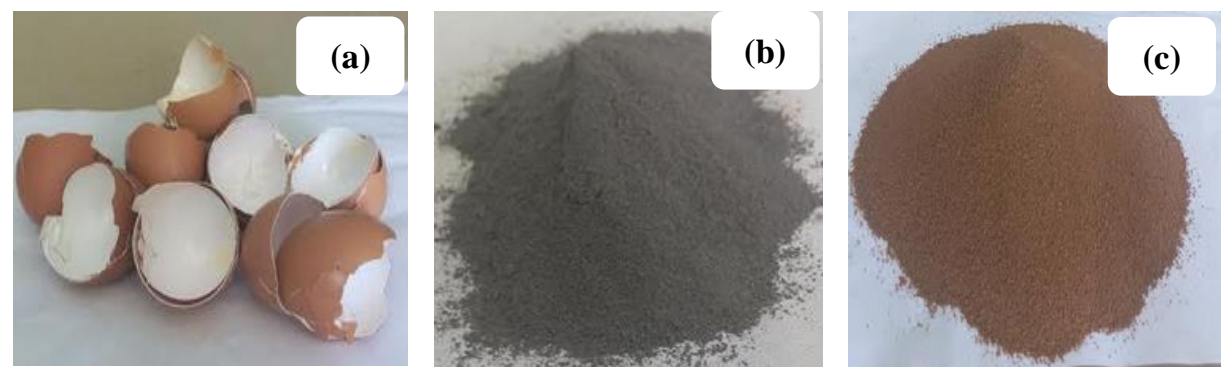

Fig. 1. Picture of a) Eggshell waste b) Calcined eggshell powder (ESP) c) Clay-soil.

The chemical composition of clay soil and the ESP powder was determined by Xray fluorescence (XRF) Model: Mini-4, PW4030, Rh X-Ray tube, 30 kV, 0.004 mA. The mineralogical phases of the raw materials and FCBs were determined by Rigaku X-ray diffraction (XRD) Model: Miniflex-600W, 2Ө, 100-240V, 50/60 Hz with $\mathrm{Cu} \mathrm{K- \alpha}$ radiation The SEM micrographs of the raw materials and fired clay bricks were viewed with a Scanning Electron Microscope (SEM) with a Model number: Zeiss, EVO, LS10. The green clay bricks were fabricated by varying the amount of raw materials, as shown in Table 1.

Table 1. Mixed raw materials compositions in (wt. \%).

\begin{tabular}{lll}
\hline & Raw materials \\
\cline { 2 - 3 } Formulation & Eggshell powder & Clay \\
\hline C-1 & 0 & 100 \\
\hline C-2 & 5 & 95 \\
\hline C-3 & 10 & 90 \\
\hline C-4 & 15 & 85 \\
\hline
\end{tabular}


The powder mixture was wet homogenized, and the resulting plastic paste was cast into a rectangular mold for production of the clay bricks with dimensions $95 \mathrm{~mm} \times 45$ $\mathrm{mm} \times 15 \mathrm{~mm}$. The produced green bricks were air-dried for seven days at room temperature and then were oven-dried at $120^{\circ} \mathrm{C}$. The dried green bricks were sintered in the carbonite tubular furnace with a model number: MF03-3.13, UK from 800-1000 ${ }^{\circ} \mathrm{C}$ at a heating rate of $8{ }^{\circ} \mathrm{C} / \mathrm{min}$ and a holding time of 120 minutes. The sintered FCBs were then cooled while in a furnace to room temperature.

The technological properties of FCBs, namely the water absorption, apparent porosity, bulk density, and compressive strength, were determined according to BS-3921 [38], whereby the FCBs were soaked in distilled water for $24 \mathrm{~h}$. A pair of Vernier calipers were used to measured the dimensions of FCBs before compressive testing was performed. The compressive strength tests of the FCBs were done by the universal testing machine (Model: M, 10,200,10-DS, Prufsyteme, Germany).

\section{Results and Discussion}

The chemical composition of clay soil contained $\sim 66.20 \%$ of $\left(\mathrm{SiO}_{2}\right)$ and $\sim$ $19.50 \%$ of alumina $\left(\mathrm{Al}_{2} \mathrm{O}_{3}\right)$. The calcined eggshell powder contained $\sim 79.28 \%$ of calcium oxide $(\mathrm{CaO})$, as shown in Table. 2. The high content of calcium oxide $(\mathrm{CaO})$ was the result of eggshell calcite $\left(\mathrm{CaCO}_{3}\right)$ decomposition into carbon dioxide $\left(\mathrm{CO}_{2}\right)$ and other organic matters at a calcination temperature of $900{ }^{\circ} \mathrm{C}$ at a heating rate of $5{ }^{\circ} \mathrm{C} \mathrm{min}^{-1}$ for $1.5 \mathrm{~h}$. The presence of high content of iron oxide $\left(\mathrm{Fe}_{2} \mathrm{O}_{3}\right) \sim 5.90 \%$ in clay soil may have contributed to the lowering of the firing temperature during a sintering process while imparting red colouration in the fired clay bricks. Additionally, the presence of $\mathrm{K}_{2} \mathrm{O}$ as fluxing agents indicates that vitrification and densification may be possible below $1000{ }^{\circ} \mathrm{C}$.

Table 2. Chemical composition of raw materials.

\begin{tabular}{lllllllllll}
\hline Raw & \multicolumn{10}{c}{ Oxides } \\
materials & $\mathrm{SiO}_{2}$ & $\mathrm{Al}_{2} \mathrm{O}_{3}$ & $\mathrm{Fe}_{2} \mathrm{O}_{3}$ & $\mathrm{CaO}$ & $\mathrm{MgO}$ & $\mathrm{Na}_{2} \mathrm{O}$ & $\mathrm{K}_{2} \mathrm{O}$ & $\mathrm{TiO}_{2}$ & $\mathrm{MnO}$ & $\mathrm{BaO}$ \\
\hline Clay soil & 66.20 & 19.45 & 5.90 & 0.14 & 1.40 & 0.42 & 1.92 & 1.30 & 0.11 & 0.12 \\
\hline ESP & 0.44 & 0.34 & 0.02 & 79.28 & 1.12 & 0.19 & 0.11 & - & - & - \\
\hline${ }^{*}$ ESP $=$ Eggshell powder & & & & & & & &
\end{tabular}

Table 3 shows changes in the physical properties of the clay soil as the eggshell powder was introduced into the clay matrix. The liquid limit (\%), plasticity limit (\%), and plasticity index $(\%)$ decreased as the content of eggshell powder was increased. The decrease in plastic behaviour of the clay-soil shows that eggshell powder is non-plastic material, as reported by Amaral et al. [19]. However, the plasticity limits (\%) of the clay soil between 15-30\% showed that eggshell powder is a non-plastic material that stabilized the clay soil and made it more suitable for the production of fired clay bricks. 
Table 3. Physical properties of the clay soil with the addition of eggshell powder content.

\begin{tabular}{llccc}
\hline $\begin{array}{l}\text { Engineering } \\
\text { properties (\%) }\end{array}$ & Clay-soil & \multicolumn{3}{l}{ Eggshell powder in weight percent (\%) } \\
\hline & 0 & 5 & 10 & 15 \\
\hline Liquid limit & 40.80 & 39.4 & 37.6 & 35.7 \\
\hline Plastic limit & 21.4 & 20.9 & 19.8 & 18.3 \\
\hline Plasticity index & 17.60 & 16.8 & 15.7 & 15.1 \\
\hline
\end{tabular}

Fig. 2a shows the surface morphology of clay sample particles that are highly agglomerated than the calcined eggshell powder, which shows its high plastic nature. However, the EDS analysis in Fig. 2b showed peaks of silicon ( $\mathrm{Si}$ ) and aluminum (Al) were observed to be high compared to other elements. The content of silicon ( $\mathrm{Si}$ ) and aluminum $(\mathrm{Al})$ in their oxide form and fluxing metal such as potassium $(\mathrm{K})$ in clay soil are essential towards the formation of mullite and glassy phases during a sintering process. On the other hand, the SEM micrograph of ESP in Fig. 2c shows scattered particles that are not agglomerated as observed in clay soil that confirms eggshell powder does not have plastic properties. However, the EDS in Fig.2d revealed the highest peak of calcium $(\mathrm{Ca})$ and the low peak of oxygen $(\mathrm{O})$, which confirm that calcium oxide $(\mathrm{CaO})$ was present in the eggshell powder.
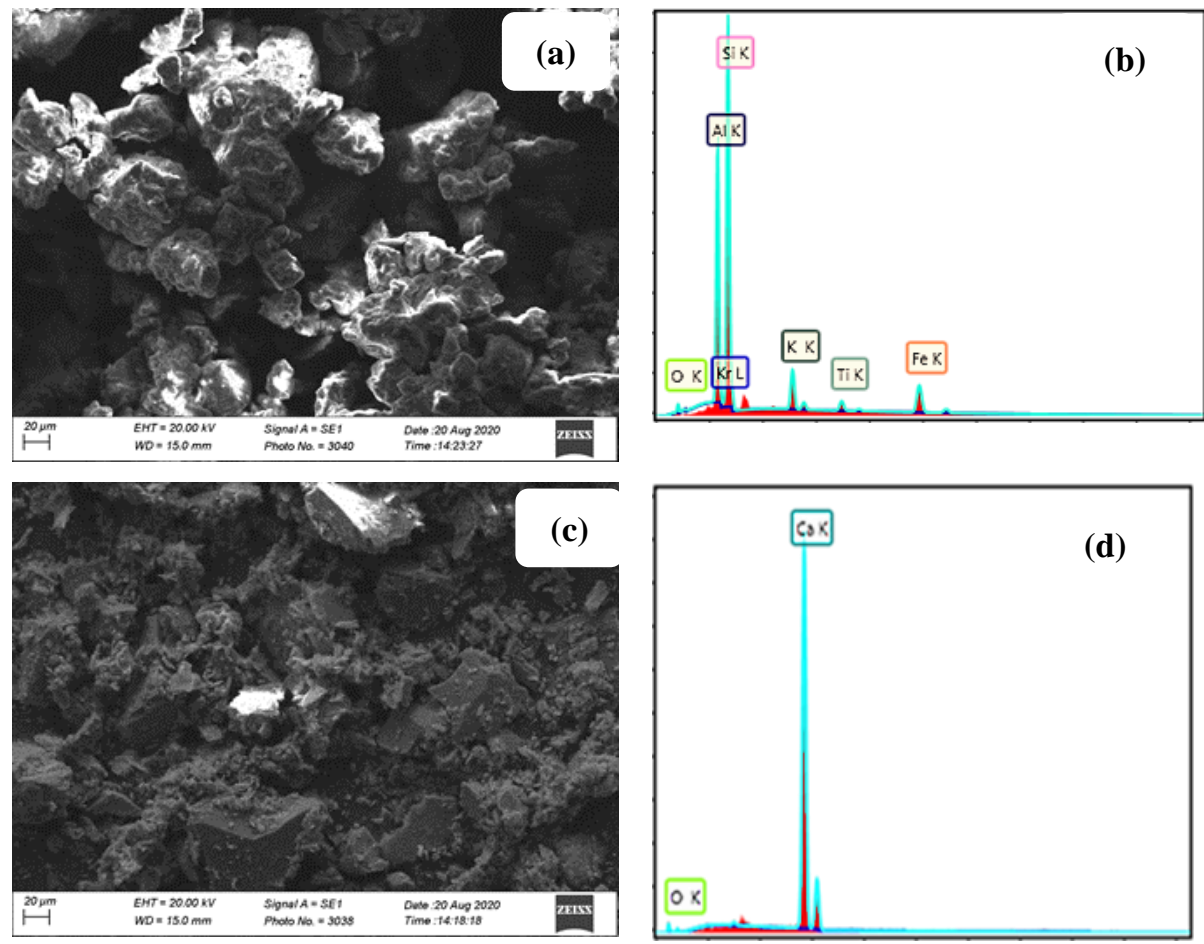

Fig. 2. a-b) SEM micrograph and EDS spectrum of clay-soil c-d) SEM micrograph and EDS spectrum of calcined eggshell powder. 
SEM micrographs of all the FCBs with and without eggshell powder are presented in Fig.3. In Fig.3(a-b) the FCBs without eggshell powder when fired at 900 and $1000{ }^{\circ} \mathrm{C}$ showed a progressive change vitrification process which was influenced by the fluxing agents found in the clay soil and the sintering temperature. However, in Fig. 3 (c-d), the FCBs with 5 wt.\% of eggshell powder showed vitrified rough surfaces as the sintering temperature was increased from 900 to $1000^{\circ} \mathrm{C}$ for a duration of $1 \mathrm{~h}$. On the other hand, in Fig. 3 (e-f), the SEM micrographs of FCBs incorporated with $10 \mathrm{wt} \%$ of eggshell powder as a flux showed a progressive change in densification and vitrification processes with some traces of scattered eggshell powder particles on the surface. But the FCBs show fractured surfaces which might have been influenced by the decomposition of calcite and expulsion of the entrapped water in the clay bricks. In Fig. 3 (g-h), the SEM micrographs of the FCBs incorporated with $15 \mathrm{wt} . \%$ of eggshell powder as a bio-filler and flux showed extensive vitrification. This might be attributed to sufficient sintering temperature at 1000 ${ }^{\circ} \mathrm{C}$ and high content of eggshell powder as a bio flux. In general, the progressive change in densification and vitrification in FCBs was due to an increase in ESP content and the sintering temperature, which greatly enhanced the technological properties of the fired clay bricks. This confirms that eggshell powder acted as a flux to influence densification and vitrification processes which greatly enhanced the technological properties of the fired clay bricks at different firing temperatures.
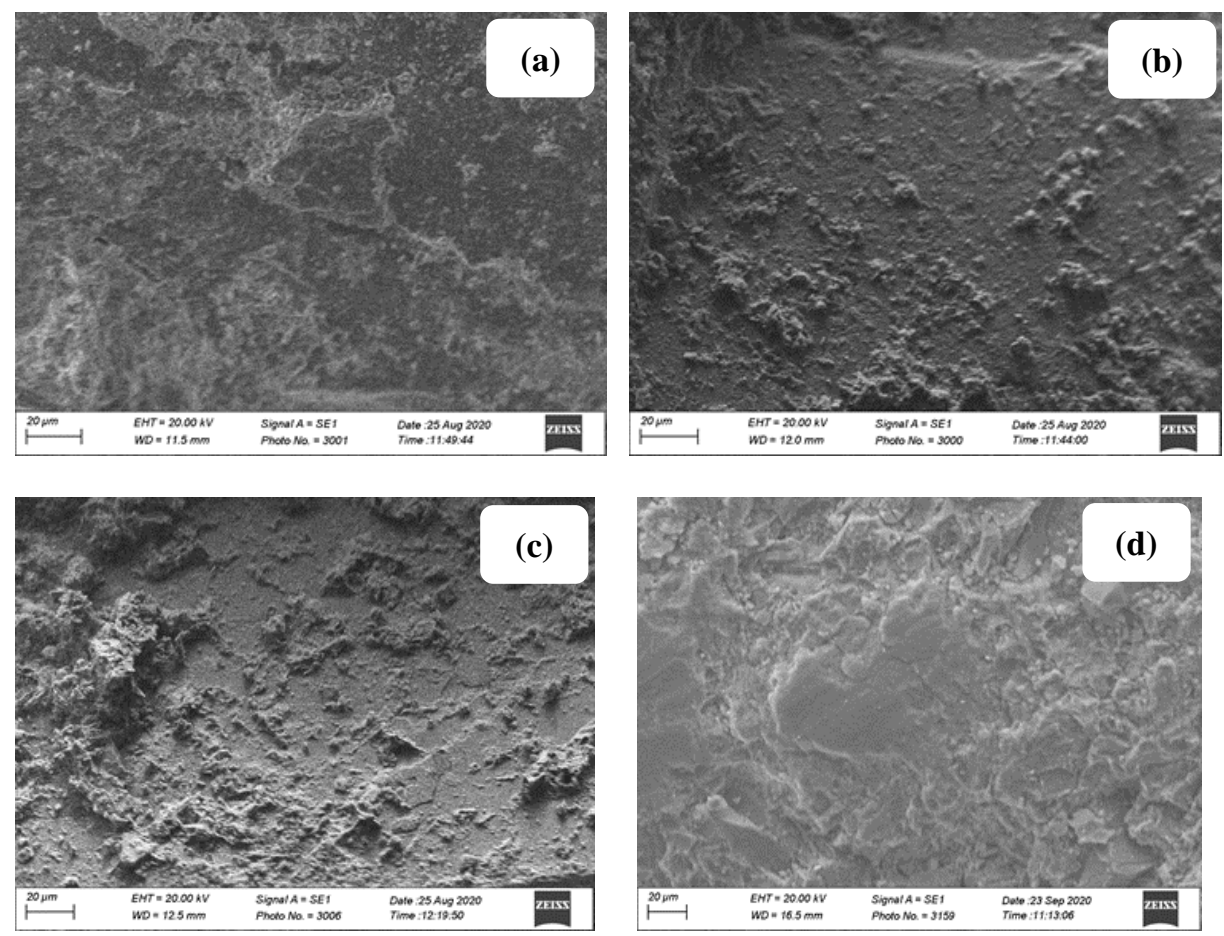

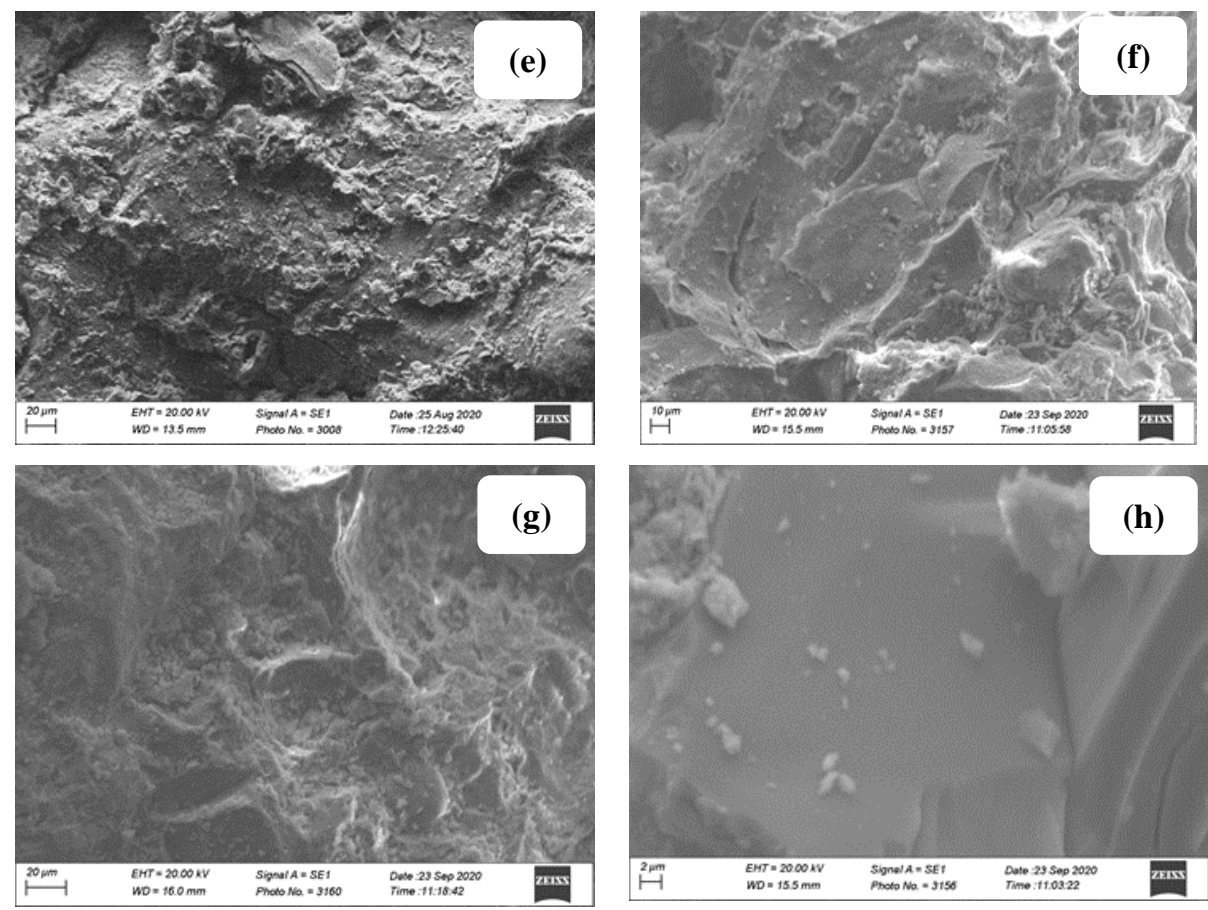

Fig. 3. SEM micrographs of FCBs $a-b) B-1$ sample with $0 \%$ of ESP $c$-d) $B-2$ with $5 \%$ of ESP e-f) B-3 with $10 \%$ of ESP $g-h$ ) B-4 with $15 \%$ of ESP fired at 900 and $1000{ }^{\circ} \mathrm{C}$.

Fig. 4 shows the X-ray diffraction peaks of eggshell powder, clay soil, and the fired clay bricks. In Fig. 4a, the X-ray diffraction peaks of eggshell powder presented the characteristics peaks of calcium oxide $(\mathrm{CaO})$ and portlandite $\mathrm{Ca}(\mathrm{OH})_{2}$ at ambient temperature. The presence of calcium oxide $(\mathrm{CaO})$ was due to the decomposition of calcite $\left(\mathrm{CaCO}_{3}\right)$ when eggshells were calcined at a temperature of $900{ }^{\circ} \mathrm{C}$ at a heating rate of $5^{\circ} \mathrm{C} \mathrm{min}^{-1}$ for $1.5 \mathrm{~h}$ as shown in the chemical equation below:

$$
\mathrm{CaCO}_{3(s)} \longrightarrow \mathrm{CaO}_{(s)}+\mathrm{CO}_{2(g)}
$$

However, the formation of portlandite in the calcined eggshell powder was attributed to the presence of moisture $\left(\mathrm{H}_{2} \mathrm{O}\right)$ in the air, which promoted hydration of calcium oxide to calcium hydroxide, as shown below.

$$
\mathrm{CaO}_{(s)}+\mathrm{H}_{2} \mathrm{O}_{(l)} \longrightarrow \mathrm{Ca}(\mathrm{OH})_{2(s)}
$$

The presence of calcium oxide/ calcium hydroxide enhanced the technological properties of the clay bricks as a flux during a sintering process. On the other hand, claysoil displayed the characteristics peaks of quartz, kaolinite, clinochlore, haematite, and a group of micas, namely muscovite and phengite. The presence of haematite might have imparted red coloration in the fired clay bricks during a sintering process. In Fig. 4b, the $\mathrm{X}$-ray diffraction patterns of the fired clay bricks without and with eggshell powder fired at $1000{ }^{\circ} \mathrm{C}$ are presented. The XRD peaks of fired clay bricks without eggshell powder 
(C-1) displayed the peaks of quartz, corundum, hematite, and anatase predominantly due to the solid-state sintering process [40]. However, the X-ray diffraction peaks of the fired clay bricks incorporated with 5,10 , and $15 \mathrm{wt} . \%$ of eggshell powder revealed the presence of quartz, anorthic phase $\left(\mathrm{CaAl}_{2} \mathrm{Si}_{2} \mathrm{O}_{8}\right)$, wollastonite $\left(\mathrm{CaSiO}_{3}\right)$, and haematite as the main mineralogical phases. The presence of the mentioned phases identified in fired clay bricks was observed to enhance the technological properties of the samples fired at $1000{ }^{\circ} \mathrm{C}$.
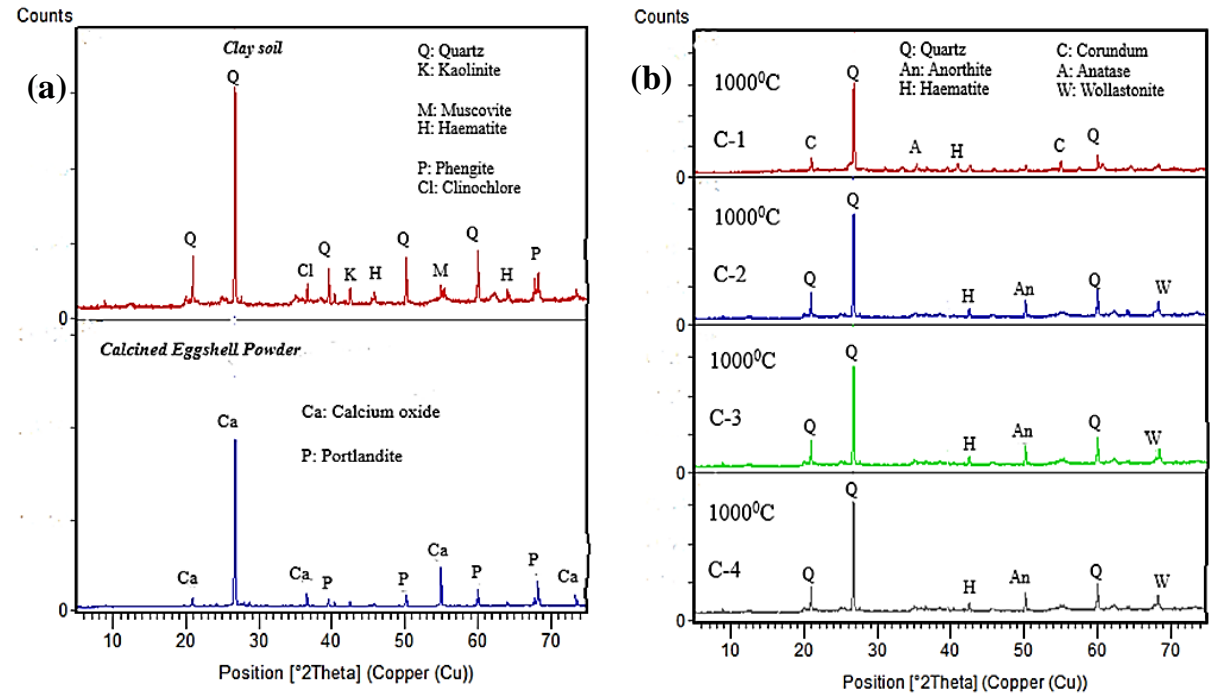

Fig. 4. X-ray Diffraction patterns of a) calcined eggshell powder and clay soil b) FCBs with 0, 5, 10 and $15 \mathrm{wt} . \%$ of eggshell powder fired at $1000{ }^{\circ} \mathrm{C}$.

\section{Technological Properties Characterization}

The technological properties of fired clay bricks, namely water absorption, apparent porosity, bulk density, and compressive strength, were determined in this study. In Fig. 5, the FCBs showed a decreasing trendy in water absorption values as the firing temperature was increased. However, the lowest values of water absorption were observed in FCBs with 5, 10, and 15 wt.\% of calcined eggshell powder. This might be influenced by the formation of the glassy phase and densification in the FCBs. The presence of $\mathrm{CaO} / \mathrm{Ca}(\mathrm{OH})_{2}$ acted as a flux to enhance vitrification of FCBs as a temperature was increased. Moreover, the FCBs with 0, 5, 10, and $15 \mathrm{wt} \%$ of eggshell powder fired at $800-1000{ }^{\circ} \mathrm{C}$ displayed water absorption values in the range of 11.1-15.6\%. 


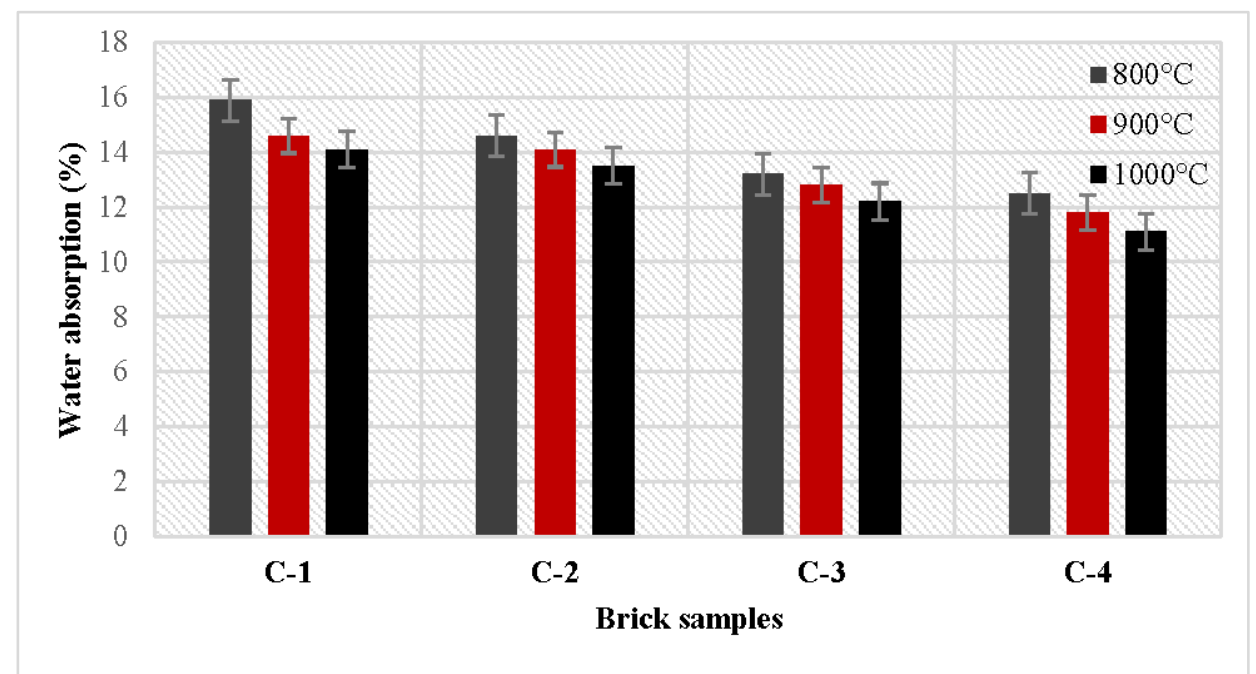

Fig. 5. Water absorption of fired clay bricks sintered at 800,900 , and $1000{ }^{\circ} \mathrm{C}$.

In Fig. 6, the apparent porosity of FCBs was observed to have a declining trendy from 800 to $1000{ }^{\circ} \mathrm{C}$. However, the lowest values of apparent porosity were observed in FCBs incorporated with eggshell powder due to densification and vitrification [35]. Furthermore, the filler effect of eggshell powder and vitrification mechanism influenced inter-particle cohesion, which reduced the number of pores in FCBs matrices. The fired clay bricks with 10 and 15 wt.\% of calcined eggshell powder displayed the lowest values of apparent porosity. The lowest apparent porosity of FCBs incorporated with eggshell powder might be attributed to the addition of $\mathrm{CaO}$ as a flux in the clay matrix, which influenced the technological properties as the firing temperature was increased.

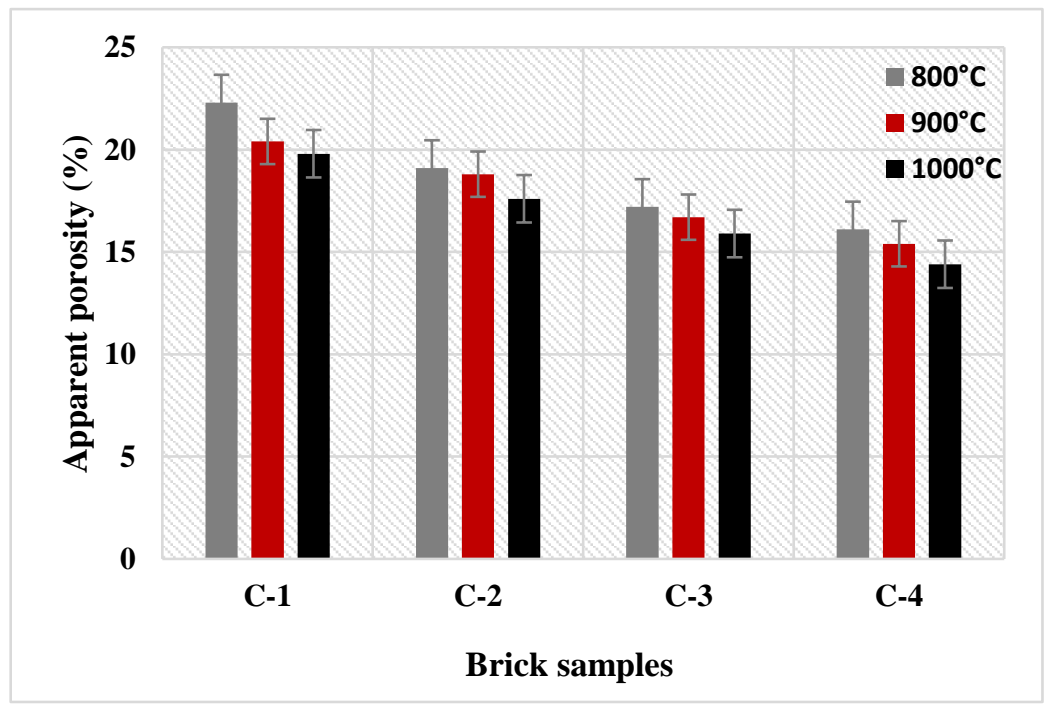

Fig. 6. apparent porosity of fired clay bricks sintered at 800,900 , and $1000{ }^{\circ} \mathrm{C}$. 
In Fig. 7, the bulk density of FCBs displayed an increasing trend with an increase in calcined ESP content and firing temperature from $800-1000{ }^{\circ} \mathrm{C}$. The mechanism might be influenced by densification due to the filler effect of ESP in the clay soil and vitrification as the result of the sintering firing process. The current experimental results are similar to the study of Tangboriboon et al. [35] and Amaral et al. [19], who reported the filler effect of eggshell powder on granulometric composition in clay-filler mixture and vitrification on high firing temperature. However, the FCBs with $15 \%$ of ESP bulk density of $2.1 \mathrm{~g} / \mathrm{cm}^{3}$ compared to other FCBs samples as a result of enhanced vitrification and densification at $1000{ }^{\circ} \mathrm{C}$, which can be considered as an energy-saving process.

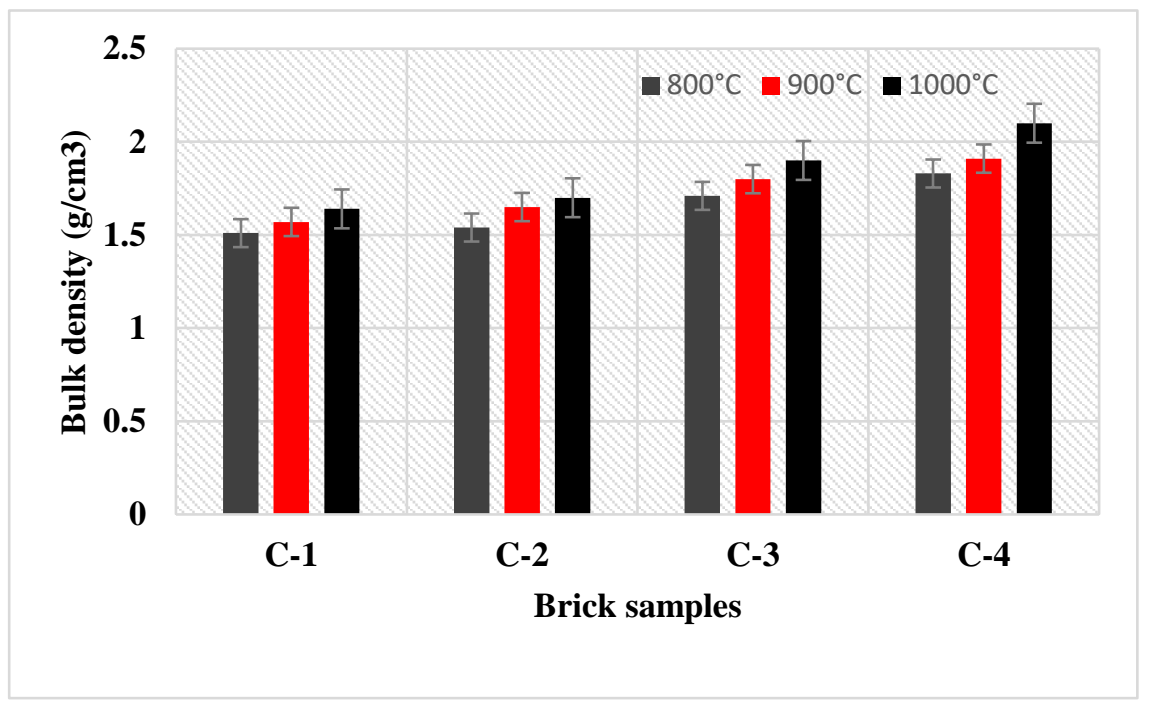

Fig. 7. Bulk density of fired clay bricks sintered fired at 800, 900, and $1000{ }^{\circ} \mathrm{C}$.

\section{Compressive Strength Characterization of the FCBs}

In Fig. 8, the compressive strength of FCBs showed an increasing trendy with an increase in calcined ESP content and sintering temperature. The incorporation of ESP enhanced the densification of FCBs during the sintering process due to its flux effect. Besides, the formation of anorthic and wollastonite phases contributed to the increase in the compressive strength of the fired clay bricks. The FCBs with 10 and 15 wt.\% of ESP were observed to have the highest compressive strength at $1000^{\circ} \mathrm{C}$. However, all FCBs incorporated with ESP gave the highest strength than those without ESP at $1000^{\circ} \mathrm{C}$, with $15 \%$ of ESP attaining the highest compressive strength of $4.8 \mathrm{MPa}$. Subsequently, the process of densification and vitrification, as well as the formation of mullite and anorthic phases, influenced the technological properties of the FCBs greatly. 


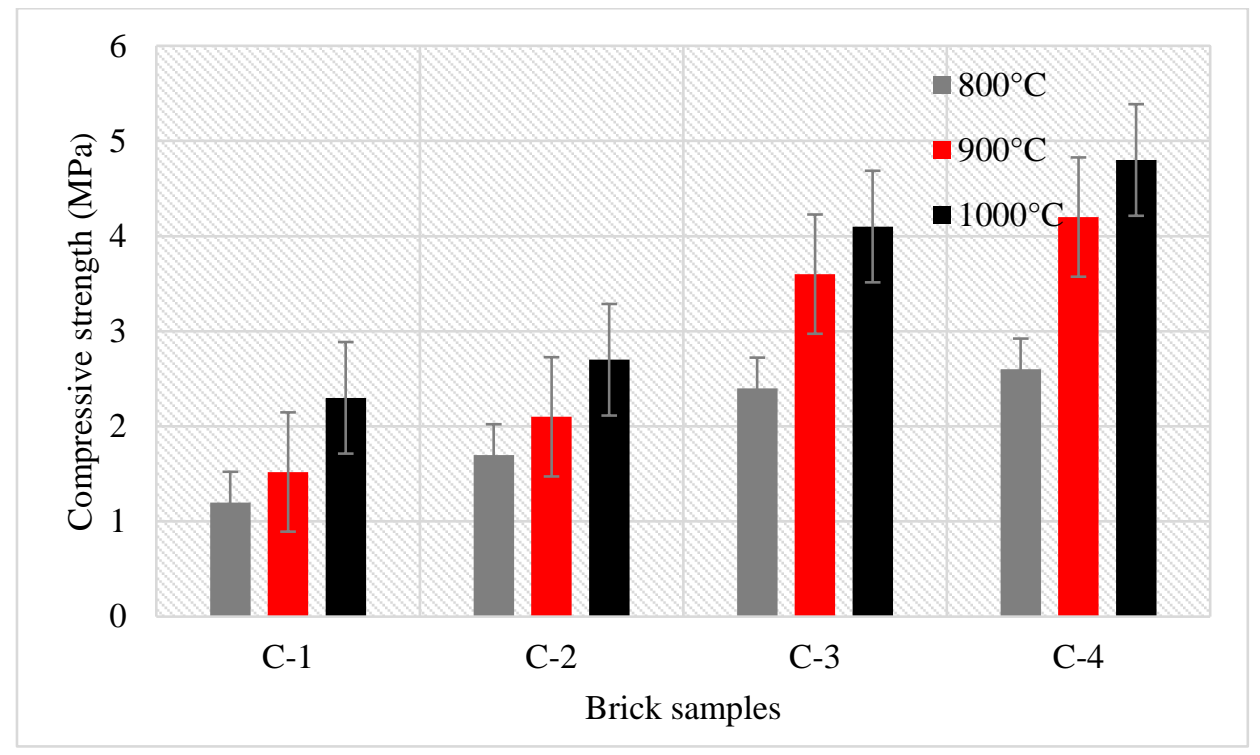

Fig. 8. Compressive strength of fired clay bricks sintered at 800,900 , and $1000{ }^{\circ} \mathrm{C}$.

\section{Conclusion}

In this research work, the eco-friendly use of ESP as a bio-filler and flux to enhance the technological properties of FCBs was experimentally investigated. Thus, incorporation and effective use of calcined ESP as a bio-filler and a flux displayed a significant improvement of the technological properties compared to FCBs with the pure clay mixture. Besides, the FCBs with $15 \%$ ESP gave the compressive strength of $4.8 \mathrm{MPa}$, the bulk density of $2.1 \mathrm{~g} / \mathrm{cm}^{3}$, and a lower water absorption value of $11.1 \%$ due to enhanced densification and vitrification at $1000{ }^{\circ} \mathrm{C}$ regarded as an energy-saving in the manufacture of FCBs. Furthermore, the formation of anorthic and wollastonite phases greatly influenced the technological properties of the fired clay bricks.

Therefore, innovative utilization of ESP as bio-filler and flux is thus considered the best eco-friendly approach in managing eggshell waste from food processing industries. Moreover, the study will give solutions to environmental concerns caused by the inappropriate dumping of eggshell waste on our environments.

\section{Acknowledgment}

My work was financially supported by the Pan African Materials Institute (PAMI) at the African University of Science and Technology (AUST) with Grant No. AUST/PAMI/2015/5415-NG. 


\section{References}

[1] J. Sutas, A. Mana, L. Pitak: Procedia Eng, 32 (2012) 1061-1067.

[2] A.A. Kadir, N.A. Sarani: Int J Integr Eng, 4 (2012) 53-69.

[3] F. Pacheco Torgal, S. Jalali: Eco-efficient Constr Build Mater, 51 (2014) 151-162.

[4] L. Aouba, C. Bories, M. Coutand, B. Perrin, H. Lemercier: Constr Build Mater, 102 (2016) 7-13.

[5] A.H. Abdullah, S. Nagapan, A. Antonyova, K. Rasiah, R. Yunus, S. Sohu: MATEC Web Conf, 103 (2017)10-28.

[6] L. Zhang: Constr Build Mater, 47 (2013) 643-655.

[7] N. Srisuwan, A, Phonphuak: J Met Mater Miner, 30 (2020) 103-108.

[8] M.J. Munir, S. Abbas, M.L. Nehdi, S.M.S. Kazmi, A. Khitab: J Mater Civ Eng, 30 (2018) 1-11.

[9] S.M.S. Kazmi, S. Abbas, M.L. Nehdi, M.A. Saleem, M.J. Munir: J Mater Civ Eng, 29 (2017) 1-12.

[10] G. Görhan, O. Şimşek: Constr Build Mater, 40 (2013) 390-396.

[11] W. Acchar, F.A. Vieira, D. Hotza: Mater Sci Eng A, 419 (2006) 306-309.

[12] M. Sutcu, S. Akkurt: Ceram Int, 35 (2009) 2625-2631.

[13] M. Sutcu, H. Alptekin, E. Erdogmus, Y. Er, O. Gencel: Constr Build Mater, 82 (2015) 1-8.

[14] R. Choudhary, S. Koppala, S. Swamiappan: J Asian Ceram Soc, 3 (2015) 173177.

[15] A. Hart: Waste Manag Res, 38 (2020) 1-14.

[16] E. Ferraz, J.A.F. Gamelas, J. Coroado, C. Monteiro, F. Rocha: Mater Struct Constr, 51 (2018) 115.

[17] A.M. Muliwa, T.Y. Leswifi, M.S. Onyango: Miner Eng, 122 (2018) 241-250.

[18] E.S. Bhagavatheswaran, A. Das, H. Rastin, H. Saeidi, S.H. Jafari, H. Vahabi, F. Najafi, H.A. Khonakdar, K. Formela, M. Jouyandeh, P. Zarrintaj, M.R. Saeb: J Polym Environ, 27 (2019) 2478-2489.

[19] M.C. Amaral, F.B. Siqueira, A.Z. Destefani, J.N.F. Holanda: Proc Inst Civ Eng Waste Resour Manag, 166 (2013) 137-141.

[20] M.R. Sarder, N.A. Hafiz, M. Alamgir: Waste Manag Resour Effic, 1 (2019) 71 79.

[21] X. Meng, D. Deng:Chem Mater, 11 (2016) 3897-3904.

[22] J. Hecht: New Sci, 2170 (1999) 6-6.

[23] S. Ummartyotin, H. Manuspiya: J Met Mater Miner, 28 (2018) 124-135.

[24] K.C. Das, M.Y. Minkara, N.D. Melear, E.W. Tollner: J Appl Poult Res, 11 (2002) 282-290.

[25] M. Felipe-Sesé, D. Eliche-Quesada, F.A. Corpas-Iglesias: Ceram Int, 37 (2011) 3019-3028.

[26] N. Mahat, Z. Yaacob, N.F. Mastan, A.F. Abd Rashid, Z. Zainordin, M.R. Mohamed Rashid, H.N. Husin, N. Khalil, M.N. Mat Noor, W.F.I. Wan Abdullah, N.A. Abd Rahman, S. Ahmad: Mod Appl Sci, 4 (2010) 119-129.

[27] A. Yerramala: Indian Concr J, 1 (2014) 94-102.

[28] Y.Y. Tan, S.I. Doh, S.C. Chin: Mag Concr Res, 70 (2018) 662-670.

[29] R. Venkata Krishnaiah, P. Dayakar, S.J. Mohan: Int J Innov Technol Explor Eng 8 (2019) 2278-3075.

[30] N.H. Abd Khalid, N.N. Abdul Rasid, A.R. Mohd Sam, N.H. Abdul Shukor Lim, L. Zardasti, M. Ismail, A. Mohamed, Z.A. Majid: IOP Conf. Ser. Mater. Sci. Eng, 220 (2019) 12047. 
[31] H. Harahap, D. Haryanto, J. Wijaya, H. Siregar, H. Nasution: AIP Conf. Proc, 2085 (2019) 20001.

[32] S.M. Hama, D.N. Hamdullah, H.M. Ashour: J Eng Sci Technol, 15 (2019) 25092521.

[33] B.W. Chong, R. Othman, P.J. Ramadhansyah, S.I. Doh, X. Li: Phys Chem Earth, 120 (2020) 102951.

[34] M. Ansari M, D. Kumar M, M. Charles J, V. G: Int J Civ Eng, 3 (2016) 1-2.

[35] N. Tangboriboon, S. Moonsri, A. Netthip, A. Sirivat: MATEC Web Conf, 78 (2016) 1003.

[36] N. Tangboriboon, S. Moonsri, A. Netthip, W. Sangwan, A. Sirivat: Sci Sinter, 51 (2019) 1-13.

[37] R. Ambika Ashwini: Int J Sci Res Dev, 7 (2019) 1047-1049.

[38] B.-3921 Standards, 1985.

[39] B.H. Ngayakamo, A. Bello, A.P. Onwualu: Environ Challenges, 1 (2020) 100006.

[40] M.P. Riccardi, B. Messiga, P. Duminuco: Appl Clay Sci, 15 (1999) 393-409.

\section{(c) (7) Creative Commons License}

This work is licensed under a Creative Commons Attribution 4.0 International License. 